\title{
The Effect of Mesenchymal Stem Cells on Fertility in Experimental Retrocervical Endometriosis
}

\section{O efeito das células-tronco mesenquimais na fertilidade em endometriose retrocervical experimental}

\author{
Jaqueline Pedroso de Abreu ${ }^{1}$ Carmen Lúcia Kuniyoshi Rebelatto ${ }^{2}$ Carolina Antunes Savari ${ }^{1}$ \\ Luiz Guilherme Achcar Capriglione ${ }^{3}$ Lye Miyague ${ }^{3}$ Lucia de Noronha ${ }^{1}$ Vivian Ferreira do Amaral ${ }^{4}$
}

\footnotetext{
${ }^{1}$ Center for Health and Biological Sciences, Pontifícia Universidade Católica do Paraná (PUC-PR), Escola de Medicina, Curitiba, Paraná, Brazil

2 Experimental Laboratory of Cell Culture, PUC-PR, Curitiba, Paraná, Brazil

${ }^{3}$ Center for Health and Biological Sciences, Escola de Ciências Agrárias e Medicina Veterinária, PUC-PR, Curitiba, Paraná, Brazil

${ }^{4}$ Department of Obstetrics and Gynecology, Universidade Federal do Paraná (UFPR), Curitiba, Paraná, Brazil
}

Rev Bras Ginecol Obstet 2017;39:217-223.

\begin{abstract}
Address for correspondnece Jaqueline Pedroso de Abreu, MSc, Departamento de Tocoginecologia - HCUFPR, Gen. Carneiro, 181 - Alto da Glória, 80060-900, Curitiba, PR, Brazil (e-mail: jaquelinepabreu@gmail.com).
\end{abstract}

Abstract

Keywords

- endometriosis

- mesenchymal stem cell

- fertility

- rabbits
Purpose To evaluate the effect of mesenchymal stem cells (MSCs) on fertility in experimental retrocervical endometriosis.

Methods A total of 27 New Zealand rabbits were divided into three groups: endometriosis, in which endometrial implants were created; mesenchymal, in which MSCs were applied in addition to the creation of endometrial implants; and control, the group without endometriosis. Fisher's exact test was performed to compare the dichotomous qualitative variables among the groups. The quantitative variables were compared by the nonparametric Mann-Whitney and Kruskal-Wallis tests. The MannWhitney test was used for post-hoc multiple comparison with Boniferroni correction. Results Regarding the beginning of the fertile period, the three groups had medians of $14 \pm 12.7,40 \pm 5$, and $33 \pm 8.9$ days respectively $(p=0.005)$. With regard to fertility (number of pregnancies), the endometriosis and control groups showed a rate of $77.78 \%$, whereas the mesenchymal group showed a rate of $11.20 \%(p=0.015)$. No differences in Keenan's histological classification were observed among the groups $(p=0.730)$. With regard to the macroscopic appearance of the lesions, the mesenchymal group showed the most pelvic adhesions.

Conclusion The use of MSCs in endometriosis negatively contributed to fertility, suggesting the role of these cells in the development of this disease. received

October 5, 2016 accepted after revision

February 2, 2017

published online

April 11, 2017
DOI https://doi.org/

10.1055/s-0037-1601484. ISSN $0100-7203$.
Copyright $\odot 2017$ by Thieme Revinter

Publicações Ltda, Rio de Janeiro, Brazil
License terms

(c) (i) $\ominus$ (\$) 


\begin{abstract}
Resumo
Palavras-chave

- endometriose

- célula-tronco mesenquimal

- fertilidade

- coelhos

Objetivo Avaliar o efeito das células-tronco mesenquimais sobre a fertilidade na endometriose retrocervical experimental.

Métodos Um total de 27 coelhas da raça Nova Zelândia foram divididas em três grupos: endometriose, em que os implantes endometriais foram criados; mesenquimal, em que as células-tronco mesenquimais foram aplicadas complementarmente à criação implantes endometriais; e controle, sem endometriose. O teste exato de Fisher foi realizado para comparar variáveis dicotômicas qualitativas entre os grupos. As variáveis quantitativas foram comparadas pelos testes não paramétricos de MannWhitney e Kruskal-Wallis. O teste de Mann-Whitney foi utilizado para a comparação múltipla pós-hoc com correção de Boniferroni.

Resultados em relação ao início do período fértil, os grupos endometriose, mesenquimal e controle tiveram medianas de $14 \pm 12,7 ; 40 \pm 5$; e $33 \pm 8,9$ dias, respectivamente $(p=0,005)$. Sobre a taxa de fertilidade (número de gravidezes), os grupos endometriose e controle mostraram uma taxa de $77,78 \%$, enquanto o grupo mesenquimal mostrou uma taxa de $11,20 \%(p=0,015)$. Não foram observadas diferenças na classificação histológica de Keenan entre os grupos $(p=0,730)$. No que diz respeito à aparência macroscópica das lesões, o grupo mesenquimal mostrou maiores adesões pélvicas.

Conclusão $\mathrm{O}$ uso de células-tronco mesenquimais na endometriose contribuiu negativamente para a fertilidade, sugerindo o papel dessas células no desenvolvimento da doença.
\end{abstract}

\section{Introduction}

Endometriosis is a disease characterized by the presence of glands and/or endometrial stroma outside the uterine cavity. $^{1}$ Endometriosis can be macroscopically divided into three clinically distinct entities: superficial peritoneal endometriosis, ovarian endometriosis (endometrioma), and deep endometriosis. ${ }^{2,3}$ Deep endometriosis is estimated to occur in $\sim 20 \%$ of women with the disease. ${ }^{4}$

The most common symptoms of endometriosis are dysmenorrhea, dyspareunia, chronic pelvic pain, and infertility, 5,6 and the deep form of the disease is often related to infertility. 5 One study reported the detection of endometriosis in $20-50 \%$ of women who underwent investigations for infertility. ${ }^{7}$

Currently, groups of scientists are researching the presence of progenitor stem cells in the endometrium and the correlation of this phenomenon with endometrial regeneration and menstrual cyclicity. ${ }^{8-11}$ In 2004, a research group led by Gargett ${ }^{12}$ demonstrated the presence of a small group of cells exhibiting clonogenic capacity in the human endometrium. ${ }^{11,13}$ In the same year, another group led by Taylor proposed that bone marrow cells in humans could participate in the endometrial regeneration process in recipient patients. ${ }^{12,14}$

Vidane et $\mathrm{al}^{15}$ suggested that mesenchymal cells derived from the bone marrow also contribute to endometrial growth and play a role in the progression of endometriosis.

Endometriosis is a disease with inflammatory characteristics. ${ }^{2,10}$ Furthermore, mesenchymal stem cells (MSCs) release factors with the following trophic properties: immunomodulatory, angiogenic, and antiapoptotic. ${ }^{16,17}$ These cells appear to need an inflammatory environment for exerting their immunomodulatory function, ${ }^{18}$ and such an environment exists in endometriosis.

Mesenchymal stem cells are considered non-immunogenic, but they can differentiate into various tissues and secrete immunomodulatory and regenerative/reparative factors. Therefore, MSCs are considered optimal for cell therapy. ${ }^{15}$ These cells are primarily used for regeneration; their effects on the immune system and the secretion of growth factors have opened fields in the clinical research. ${ }^{16}$

The complexity of the pathophysiology of endometriosis, the heterogeneity of the disease in humans, and the effect of mesenchymal cells as immunomodulators are still controversial. ${ }^{19}$ In this context, female rabbits are a good choice as experimental models. They have homogeneous lesions-that is, generally solid and hemorrhagic masses-that can be easily created by autograft of endometrial fragments or by the opening and exposure of the endometrial cavity. ${ }^{20}$

The objective of this study was to evaluate the possible contribution of MSCs for the development of endometriosis and its effects on fertility through induced lesions in rabbits.

\section{Methods}

This experimental study was conducted after approval by the Animal Ethics Committee of the university (CEUA- PUCPR, project no. 710 C).A total of 29 adult female New Zealand rabbits (6-8 months of age) weighing between 3 and $4 \mathrm{~kg}$ were used. This total included 27 rabbits used for the sample and 2 for bone marrow collection. 
The surgical procedures and the extraction and cultivation of MSCs were performed at the Operative Technique and Experimental Surgery Laboratory and the Cell Therapy Laboratory, both located at the same university in southern Brazil.

All handling of the animals followed the rules of the Council for International Organization of Medical Sciences (CIOMS), the Ethical Code for Animal Experimentation ${ }^{21}$ and the precepts of the Colégio Brasileiro de Experimentação Animal (COBEA, www.cobea.org.br).

The rabbits were divided into three groups of nine each: control group (C), endometriosis group (E), and mesenchymal group (M). In the endometriosis group, a technique developed by do Amaral et al was performed: ${ }^{19}$ a median incision was initially made in the abdominal wall. Then, a 4-cm piece was removed from the right uterine horn. Patches $5 \times 5 \mathrm{~mm}$ in size were created and sutured in the retrocervical region.

In the control group, a fragment of the uterine horn was removed following the procedure described before. However, the endometrial implant was not sutured in these animals. The mesenchymal group was submitted to the same procedure as the endometriosis group, and later, also submitted to the application of mesenchymal cells.

In all three groups there was a delay of 21 days before copulation was initiated. This is the minimum time required for disease development to occur or for the implanted endometrium to become secretory. In the Endometriosis and Control groups the copulations occurred after the first surgery. Alredy in the Mesenchymal group, the copulation only started after 21 days of the second surgical procedure (application of the mesenchymal cells).
Copulation occurred 4, 6, and 9 weeks after surgery, when the rabbits were fertile. To check fertility, we evaluated the coloring of the vulva daily, and females with red/violet vulva (unlike the normal whitish color) ${ }^{23}$ were placed in a cage with a male for mating. Abdominopelvic ultrasounds were performed, and the animals were then checked for signs of pregnancy (the presence of a gestational sac or fetus). - Fig. 1 shows a flowchart with a brief description of the chronology of the experiments in the study.

Mesenchymal stem cells were obtained 12 weeks before the application by extracting bone marrow from the long bones of two rabbits. The femur and tibia were removed, and all tissue was scraped away from the bones. The bones were placed in a Petri dish containing phosphate buffered saline (PBS; Gibco Invitrogen, NY, USA). The epiphyses were cut to expose the medullary cavity. The marrow was removed from each bone with flushing medium into a tube (TPP, Trasadingen, Switzerland) using a syringe with a needle.

The collected bone marrow was processed using a Ficoll-Hypaque density gradient $(\mathrm{d}=1.077 \mathrm{~g} / \mathrm{mL}$; Sigma Chemical, St Louis, USA). ${ }^{24}$ The isolated mononuclear cells were plated in $75-\mathrm{cm}^{2}$ flasks (TPP), and were cultivated using IMDM (Iscove's Modified Dulbecco's Media; Gibco Invitrogen) medium containing $15 \%$ fetal calf serum (FCS; Gibco Invitrogen) and $1 \%$ antibiotics. The cultures were maintained in an incubator, and the culture medium was changed every 72 hours. Upon reaching $80 \%$ confluence, the cells were trypsinized using a trypsin-EDTA solution (Gibco Invitrogen), and were subcultured to obtain the required number of cells for potency tests and transplantation.

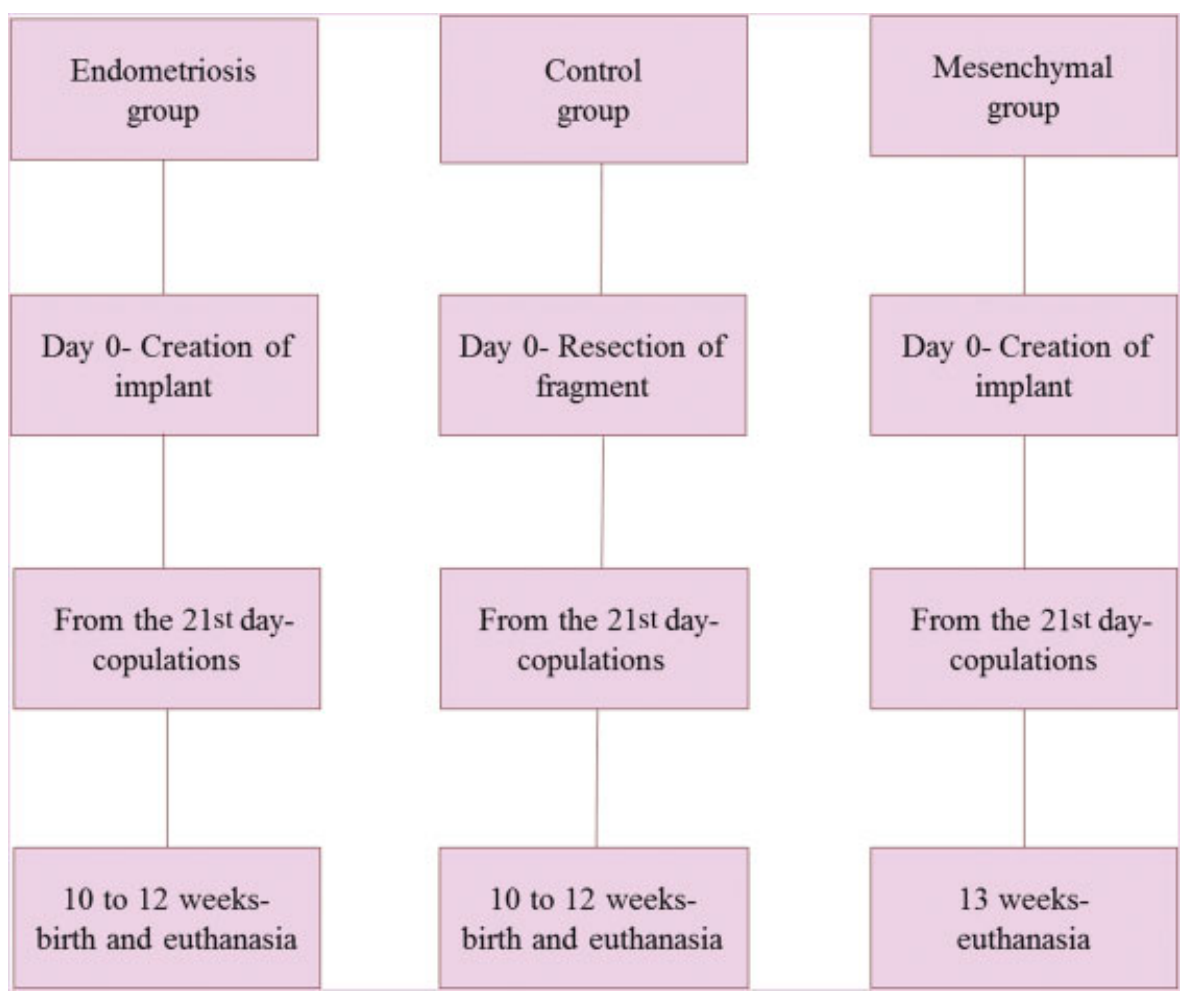

Fig. 1 Chronology of the experiments in the study. 


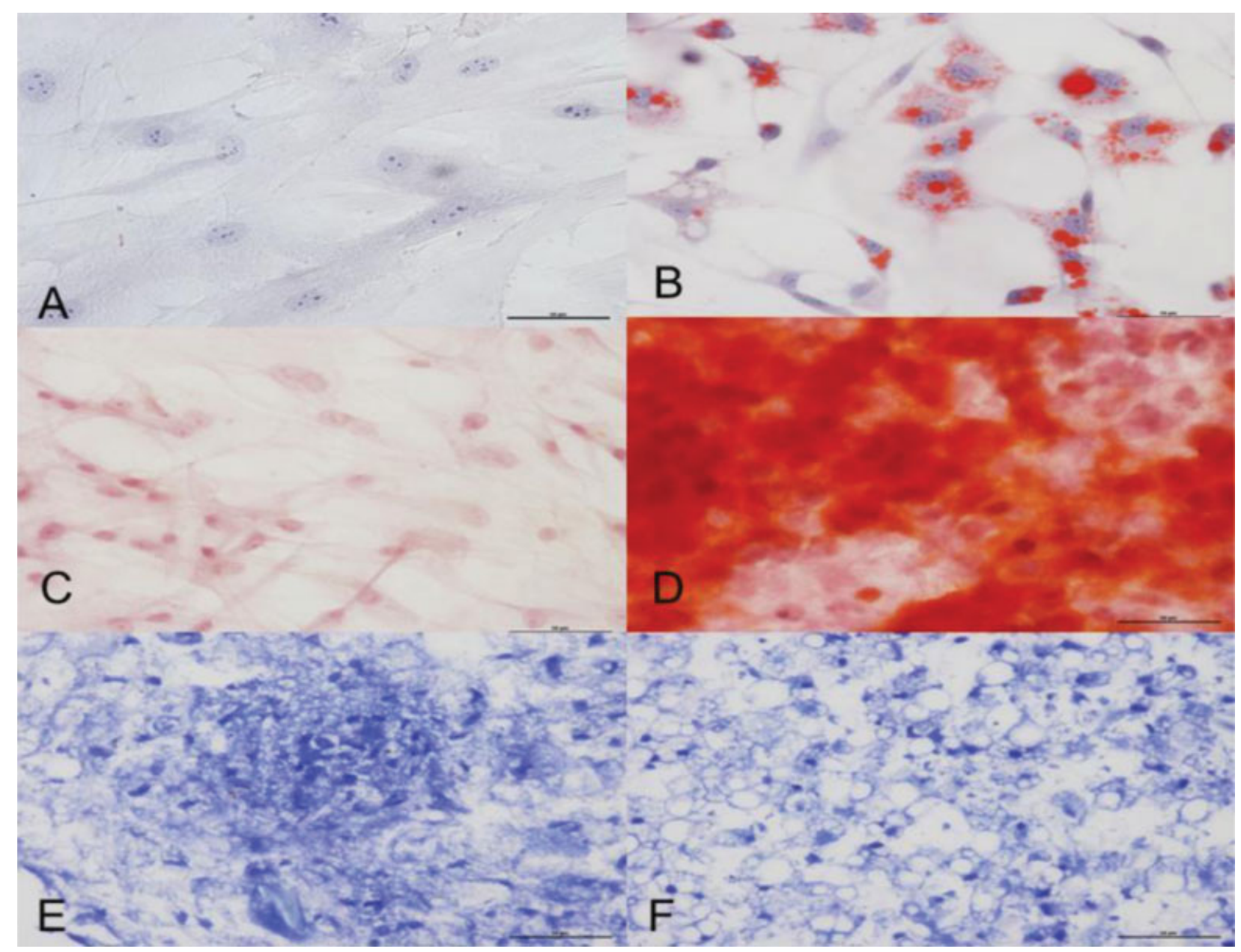

Fig. 2 (A-F) Differentiation of mesenchymal cells. (B) The differentiation into the adipocyte lineage was demonstrated by staining with Oil Red O; (D) Alizarin Red S staining shows mineralization of the extracellular matrix in the osteogenic differentiation; and (F) toluidine blue shows the deposition of proteoglycans and lacunae in the chondrogenic differentiation. (A, C, E) Untreated control cultures without adipogenic, osteogenic or chondrogenic differentiation stimuli are shown.

The MSCs were assessed for potency by inducing their differentiation into adipocytes, osteoblasts, and chondrocytes ( - Fig. 2 A-F). For adipogenic and osteogenic differentiation, cells were seeded on glass coverslips (Sarstedt, Newton, USA) in 24-well plates. A commercial differentiation medium (Gibco Invitrogen) was used for 21 days. The MSCs were stained with Oil Red $\mathrm{O}$ to analyze adipogenic induction. Large, rounded cells with cytoplasmic lipid-rich vacuoles were observed. Osteogenic differentiation was assessed by visualizing the mineralization of the extracellular matrix with Alizarin Red S staining.

Cells were grown in a micromass culture to promote chondrogenic differentiation. ${ }^{25}$ In the chondrogenic differentiation assays, high-density micromass MSC cultures generated cellular nodules, which produced large amounts of cartilage-related extracellular matrix molecules, such as collagen. Paraffin sections of the aggregates stained with toluidine blue showed condensed structures with cuboidal cells and chondrocyte-like lacunae.

Untreated control cultures, which were grown in regular medium without adipogenic, osteogenic, or chondrogenic differentiation stimuli, did not exhibit spontaneous adipocyte, osteoblast, or chondrocyte formation after 21 days of MSC cultivation.

After 21 days, in the Mesenchymal group, the second surgery for the application of the mesenchymal cells was also performed.

During this reoperation, the size of the lesion formed by the implant was checked. All the implants were considered viable (with an area not exceeding $25 \mathrm{~cm}^{2}$ ). We used $2 \times 10^{6}$ cells in each animal ( $2 \mathrm{ml}$ in a syringe), which were applied on the edge of the implant.

For the histological analysis, endometrial implants fixed in formalin were prepared in paraffin blocks. These samples were later sectioned at a thickness of $5 \mu \mathrm{m}$ (4 cuts per sample), stained with hematoxylin and eosin, and evaluated with an optical microscope. The lesions were classified according to Keenan's index. ${ }^{26}$ Scores were assigned as follows: score of $3: \mathrm{a}$ well-preserved epithelial layer; score of 2 : moderately preserved epithelium with leukocyte infiltration; score of 1 : poorly preserved epithelium (occasional epithelial cells only); and score of 0: no epithelium (-Fig. 3 A-B). 


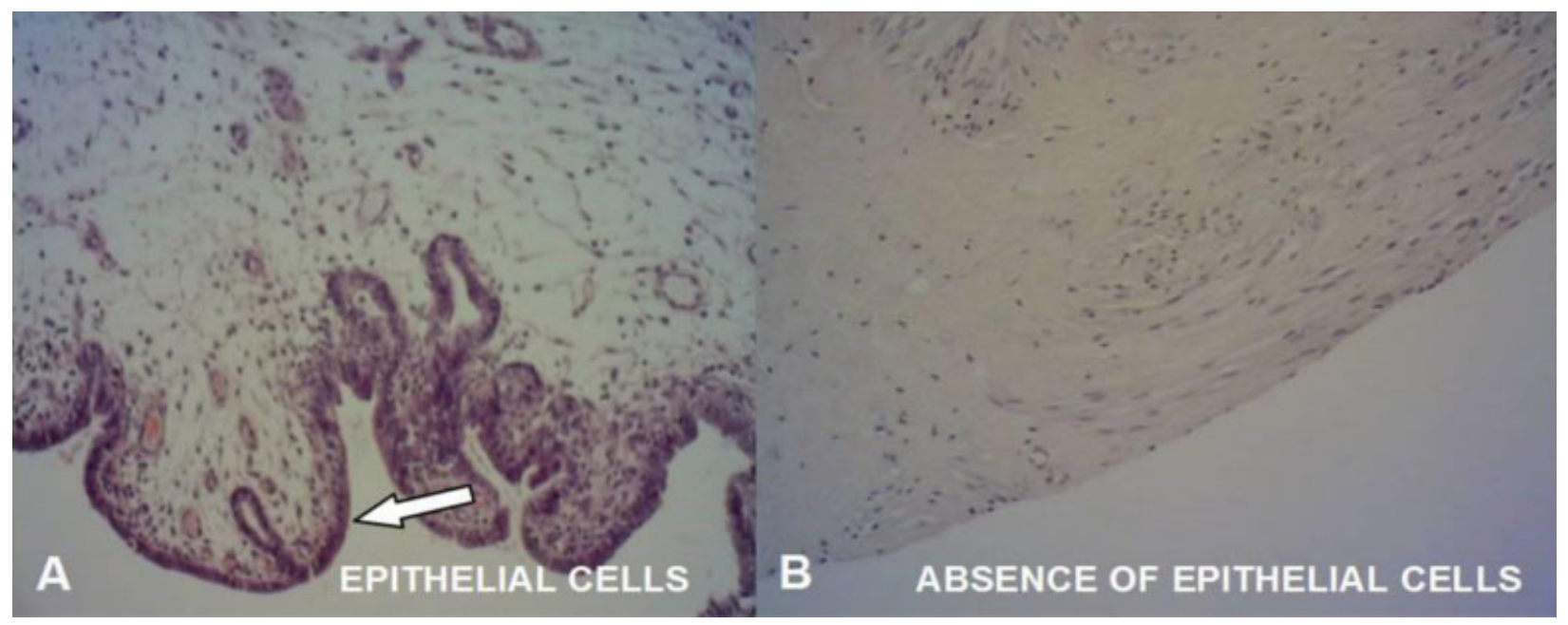

Fig. 3 (A) Histological image of the endometrial implant with a Keenan index of 3. (B) Histological picture of the endometrial implant with a Keenan index of 0 .

The sample size was based on similarity with other articles; to control Type II Error in the applied tests, test power was used.

Qualitative variables were described as frequencies and percentages, and quantitative variables were described as means, medians, and quartiles. Fisher's exact test was performed to compare dichotomous qualitative variables among the groups. The quantitative variables were compared by the nonparametric Mann-Whitney and Kruskal-Wallis tests. The Mann-Whitney test was used for post-hoc multiple comparison with Boniferroni correction. Values of $p<0.05$ were considered statistically significant. The data were analyzed with the Statistical Package for the Social Sciences (SPSS; IBM SPSS, Chicago, IL, US) software, version 20.0.

\section{Results}

The mesenchymal group had the worst fertility rate (11.1\%; $p=0.015$; test power: $84.29 \%$; only one animal in this group became pregnant. In contrast, seven rabbits in the control group and seven in the endometriosis group (77.8\%) became pregnant.

After having executed the surgical procedures and waited 21 days, the time to start fertility was different between the groups. The mesenchymal group had the longest delay when compared with the other groups $(p=0.005$; test power: 92.24\%) (-Table 1). Considering a significant difference found among the groups, they were compared two by two.

Table 1 Comparison of time until the onset of the fertile period (in days) in the three groups

\begin{tabular}{|l|l|l|}
\hline Groups & $\mathbf{n}$ & Span in days \\
\hline Endometriosis & 9 & $33[18-34]$ \\
\hline Mesenchymal & 9 & $14[14-16]$ \\
\hline Control & 9 & $40[33-40]$ \\
\hline
\end{tabular}

Note: Nonparametric test of Kruskal-Wallis; $p<0.05$; median $\left[1^{\text {st }}-3^{\text {rd }}\right.$ quartiles]; Test power $=92.24 \%$.
The $p$ values and the test power of these comparisons are shown in the -Table 2.

The endometriosis group had 2 fetal deaths (28.57\%) and 5 live births (71.43\%). The control group had 7 pregnancies, which resulted in 2 fetal deaths (28.57\%), 3 abortions (42.86\%), and 2 live births (28.57\%).

There was no difference in implant size between the endometriosis (median $=55,1$ st quartile $=15$, and $3 \mathrm{rd}$ quartile $=90$ ) and mesenchymal groups (median $=55,1$ st quartile $=25$, and 3rd quartile $=80 ; p=0.863$ ).

Macroscopically, the formation of a large adhesion in the cavity was noted in the mesenchymal group, even making it difficult to identify the implants (-Fig. 4A). Comparatively, a minor amount of adhesion was noticed in the endometriosis group (-Fig. 4B). Finality, discrete adhesion formation was observed in the control group. Despite the formation of adhesions, endometriotic lesions were only found in the sites implanted, and no dissemination was observed.

The persistence of epithelial cells in the endometrial implants was assessed semi-quantitatively with Keenan's index $^{26}$ (-Fig. 3 A-B). The following results were observed among the nine analyzed rabbits in each group. The endometriosis group included 3 rabbits with a Keenan index of 0 , and 6 with a Keenan index of 3, and the mesenchymal group included 2 rabbits with a Keenan index of 0 and 7 with a Keenan index of $3(p=0.730)$.

Table 2 Test power and $p$ values in the inter-group comparison of time until the onset of the fertile period

\begin{tabular}{|l|l|l|}
\hline Groups & $p$ & Test power \\
\hline Control x Endometriosis & 0.061 & 0.3314747 \\
\hline Control x Mesenchymal & 0.043 & 0.7495601 \\
\hline Endometriosis x Mesenchymal & $<0.001$ & 0.9583571 \\
\hline
\end{tabular}

Note: Nonparametric test of Kruskal-Wallis; $p<0,05$. 


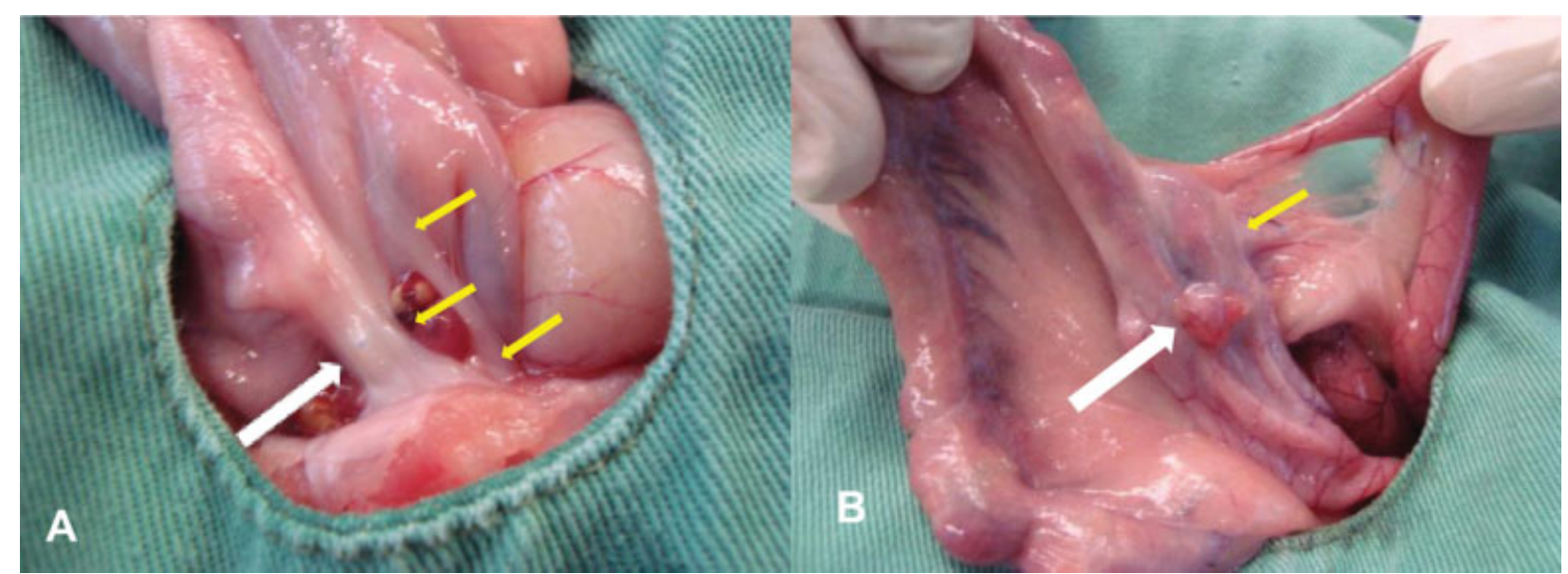

Fig. 4 (A) Mesenchymal group: large presence of adhesions (yellow arrows) that made it difficult for the implant to adhere (white arrows); (B) Endometriosis group: presence of a minor amount of adhesion (yellow arrow) next to the implant (white arrow).

\section{Discussion}

The selection of rabbits as an experimental model was based on their efficacy for developing ectopic endometrial foci in the abdominal wall. ${ }^{8}$ It is known that the production of various cytokines occurs in endometriosis, which generally stimulates endometrial proliferation and contributes to the production of acute-phase inflammatory proteins, creating a pro-inflammatory environment. ${ }^{22}$ It is also known that in endometriosis, the endometrial cells exhibit the characteristics of chronicity and expansion, showing capacities for migration, invasion, and apoptosis resistance. ${ }^{9}$

This scenario has led to new theories exploring the involvement of the immune system, such as immunological mechanisms facilitating the development of endometriosis, or the immune system being activated by it. ${ }^{9}$ The involvement of stem cells (particularly of the mesenchymal lineage) in the origin of the disease has also been proposed. ${ }^{11,12,15}$ In contrast with the reports on endometriosis leading to infertility, ${ }^{6,27}$ the development of endometriosis in the rabbits did not worsen the fertility rate. However, the rabbits were not a good model for endometriosis-related infertility. The use of the obtained MSCs caused the relative risk of infertility to increase 4-fold in these animals.

One mechanism that may explain the aforementioned result involves the pathophysiology of the disease. The evidence of stem cells in the human endometrium and the suggestion of the presence of stem cells-specifically the mesenchymal lineage ${ }^{8}$-may be related to the worsening of the fertility rate in the group that received mesenchymal cells, because we used cells that may be involved in the origin and progression of the disease.

Another mechanism that may be involved is the epithelial-mesenchymal transition (a process comprising a series of changes in epithelial cell phenotype that causes epithelial cells to assume the characteristics of MSCs, such as having a greater capacity for migration, invasion, and apoptosis resistance). ${ }^{28}$ Because endometriotic cells in the context of endometriosis also take on this function, ${ }^{8,9,28,29}$ they represent a sum of the effects of both mechanisms.

A question remains regarding whether the mesenchymal group's delay in entering the fertile period was related to the involvement of MSCs in the origin and progression of endometriosis.

With regard to obstetric outcomes, the endometriosis and control groups showed no statistically significant difference. This result may be because of the small sample size. The mesenchymal group requires further analysis because of its low fertility rate.

The macroscopic evaluation of the pelvic cavity of each animal (during euthanasia) revealed that the mesenchymal group had a greater rate of adhesions than the other groups, in an analogy with the widely used Revised Classification of the American Society for Reproductive Medicine (ASRM)..$^{30}$ Thus, we could consider the mesenchymal group a carrier of stage-IV disease (severe endometriosis with dense and firm adhesions).

It is known that anatomical distortion and adhesions are some of the mechanisms that generate infertility in the context of endometriosis. ${ }^{4,21,31}$ This mechanism may explain why the group that received MSCs on the endometrial implants may have had a low fertility rate: its higher rate of pelvic adhesions.

Finally, a histological analysis of the implants using Keenan's index was performed. This index measures the persistence of epithelial cells in endometrial implants. ${ }^{26} \mathrm{~A}$ comparison of the two groups revealed no statistically significant difference in the scores of Keenan's index.

Although it may be possible that the worsening of fertility in the mesenchymal group can be explained by two other mechanisms (the longer time the animals were exposed to the implants and the occurrence of two surgical procedures in this group), in this study design, according to our results, we can conclude that applying MSCs on female rabbits via endometrial implants provides a substrate for the development of endometriosis and thus harms fertility in these animals. 
Declaration of Conflicting Interests

The Authors have no conflicts of interest to declare.

\section{Acknowledgments}

We would like to thank the teams from Vivarium, from the Operative Technique Laboratories, and from the Cell Therapy and Pathology Departments of Pontifícia Universidade Católica do Paraná (PUC-PR) for their dedication and support.

\section{References}

1 Burney RO, Giudice LC. Pathogenesis and pathophysiology of endometriosis. Fertil Steril 2012;98(03):511-519

2 Nisolle M, Donnez J. Peritoneal endometriosis, ovarian endometriosis, and adenomyotic nodules of the rectovaginal septum are three different entities. Fertil Steril 1997;68(04):585-596

3 Lafay Pillet MC, Huchon C, Santulli P, Borghese B, Chapron C, Fauconnier A. A clinical score can predict associated deep infiltrating endometriosis before surgery for an endometrioma. Hum Reprod 2014;29(08):1666-1676

4 Porto BTC, Ribeiro HSAA, Galvão MAL, Sekula VG, Aldrigui JM, Ribeiro PAA. [Histological classification and quality of life in women with endometriosis]. Rev Bras Ginecol Obstet 2015;37(02):87-93

5 Stratton P. The association of clinical symptoms with deep infiltrating endometriosis: the importance of the preoperative clinical assessment. Hum Reprod 2014;29(08):1627-1628

6 Oliveira R, Musich DS, Ferreira MPSF, Vilarino FL, Barbosa CP. Perfil epidemiológico das pacientes inférteis com endometrioses. Reprod Clim 2015;30(01):5-10

7 Eskenazi B, Warner ML. Epidemiology of endometriosis. Obstet Gynecol Clin North Am 1997;24(02):235-258

8 Li T, He H, Liu R, Wang SX, Pu DM. Isolation and identification of epithelial and stromal stem cells from eutopic endometrium of women with endometriosis. Eur J Obstet Gynecol Reprod Biol 2014; 178:89-94

9 Figueira PGM, Abrão MS, Krikun G, Taylor HS. Stem cells in endometrium and their role in the pathogenesis of endometriosis. Ann N Y Acad Sci 2011;1221:10-17

10 Jing Z, Qiong Z, Yonggang W, Yanping L. Rat bone marrow mesenchymal stem cells improve regeneration of thin endometrium in rat. Fertil Steril 2014;101(02):587-594

11 Chan RW, Schwab KE, Gargett CE. Clonogenicity of human endometrial epithelial and stromal cells. Biol Reprod 2004;70(06):1738-1750

12 Gargett CE. Stem cells in gynaecology. Aust N Z J Obstet Gynaecol 2004;44(05):380-386

13 Deane JA, Gualano RC, Gargett CE. Regenerating endometrium from stem/progenitor cells: is it abnormal in endometriosis, Asherman's syndrome and infertility? Curr Opin Obstet Gynecol 2013;25(03):193-200
14 Du H, Taylor HS. Stem cells and female reproduction. Reprod Sci 2009;16(02):126-139

15 Vidane AS, Zomer HD, Oliveira BMM, et al. Reproductive stem cell differentiation: extracellular matrix, tissue microenvironment, and growth factors direct the mesenchymal stem cell lineage commitment. Reprod Sci 2013;20(10):1137-1143

16 Dhesi AS, Morelli SS. Endometriosis: a role for stem cells. Womens Health (Lond) 2015;11(01):35-49

17 Mundra V, Gerling IC, Mahato RI. Mesenchymal stem cell-based therapy. Mol Pharm 2013;10(01):77-89

18 Doorn J, Moll G, Le Blanc K, van Blitterswijk C, de Boer J. Therapeutic applications of mesenchymal stromal cells: paracrine effects and potential improvements. Tissue Eng Part B Rev 2012;18(02):101-115

19 do Amaral VF, Dal Lago EA, Kondo W, Souza LC, Francisco JC. Development of an experimental model of endometriosis in rats. Rev Col Bras Cir 2009;36(03):250-255

20 De Miguel MP, Fuentes-Julián S, Blázquez-Martínez A, et al. Immunosuppressive properties of mesenchymal stem cells: advances and applications. Curr Mol Med 2012;12(05): 574-591

21 Howard-Jones N. A CIOMS ethical code for animal experimentation. WHO Chron 1985;39(02):51-56

22 Schor E, Freitas V, Soares Júnior JM, Simões MJ, Baracat EC. Endometriosis: experimental model in rats. Rev Bras Ginecol Obstet 1999;21(05):281-284

23 Risi E. Control of reproduction in ferrets, rabbits and rodents. Reprod Domest Anim 2014;49(Suppl 2):81-86

24 Böyum A. Isolation of mononuclear cells and granulocytes from human blood. Isolation of monuclear cells by one centrifugation, and of granulocytes by combining centrifugation and sedimentation at $1 \mathrm{~g}$. Scand J Clin Lab Invest Suppl 1968;97:77-89

25 Johnstone B, Hering TM, Caplan AI, Goldberg VM, Yoo JU. In vitro chondrogenesis of bone marrow-derived mesenchymal progenitor cells. Exp Cell Res 1998;238(01):265-272

26 Keenan JA, Williams-Boyce PK, Massey PJ, Chen TT, Caudle MR, Bukovsky A. Regression of endometrial explants in a rat model of endometriosis treated with the immune modulators loxoribine and levamisole. Fertil Steril 1999;72(01):135-141

27 Amaral VF, Maestrelli PC, Francisco JC, et al. Bone marrow derived mononuclear stromal cells and experimental model of deep endometriosis. Int J Clin Exp Pathol 2016;9(02):1116-1126

28 Matsuzaki S, Darcha C. Epithelial to mesenchymal transition-like and mesenchymal to epithelial transition-like processes might be involved in the pathogenesis of pelvic endometriosis. Hum Reprod 2012;27(03):712-721

29 Du X, Yuan Q, Qu Y, Zhou Y, Bei J. Endometrial mesenchymal stem cells isolated from menstrual blood by adherence. Stem Cells Int 2016;2016:3573846

30 Revised American Society for Reproductive Medicine Classification of Endometriosis. Fertil Steril 1996;67(05):817-821

31 de Ziegler D, Borghese B, Chapron C. Endometriosis and infertility: pathophysiology and management. Lancet 2010;376(9742): 730-738 